Jurnal Keperawatan Silampari

Volume 5, Nomor 1, Desember 2021

e-ISSN: 2581-1975

p-ISSN: 2597-7482

DOI: https://doi.org/10.31539/jks.v5i1.1872

\title{
TERAPI SPRITUAL EMOTIONAL FREEDOM TECHNIQUE (SEFT) TERHADAP TINGKAT KECEMASAN PADA KELUARGA PASIEN YANG KRITIS
}

\author{
Wa Ode Rahmadania ${ }^{1}$, Wa Ode Aisa Zoahira ${ }^{2}$ \\ Sekolah Tinggi Ilmu Kesehatan Mandala Waluya Kendari ${ }^{1,2}$ \\ waod2020123@gmail.com ${ }^{1}$
}

\begin{abstract}
ABSTRAK
Penelitian ini bertujuan untuk mengetahui pengaruh terapi SEFT terhadap tingkat kecemasan pada keluarga pasien yang kritis di RSUD Kota Kendari. Penelitian ini menggunakan metode quasi eksperimen dengan one group pretest - posttest design. Hasil penelitian ini secara statistik dan klinis menunjukan bahwa ada pengaruh terapi SEFT terhadap tingkat kecemasan keluarga pasien yang kritis dengan nilai $p=0,001(p<0,05)$ dan nilai selisih rerata kecemasan $>10$. Pada penelitian ini terjadi penurunan tingkat kecemasan dari cemas berat (pretest) menjadi cemas sedang setelah dilakukan terapi SEFT (posttest). Meskipun penurunannya hanya sampai cemas sedang, akan tetapi keluarga pasien mengatakan menjadi lebih tenang dan muncul perasaan pasrah akan kondisi anggota keluarganya yang sedang kritis. Penurunan kecemasan tersebut juga ditandai dengan adanya penurunan frekuensi denyut nadi dan pernapasan menjadi normal setelah diberikan terapi SEFT. Simpulan, SEFT berpengaruh terhadap penurunan tingkat kecemasan keluarga pasien yang kritis.
\end{abstract}

Kata Kunci: Kecemasan, Pasien Kritis, Spiritual Emotional Freedom Technique, Visual Analog Scale for Anxiety

\begin{abstract}
This study aims to determine the effect of SEFT therapy on anxiety levels in families of critically ill patients at the Kendari City Hospital. This study uses a quasi-experimental method with one group pretest-posttest design. The results of this study statistically and clinically showed an effect of SEFT therapy on the anxiety level of the critically ill patient's family with a p-value $=0.001$ ( $p<0.05)$ and the mean difference in anxiety value $>10$. In this study, there was a decrease in anxiety levels from severe anxiety. (pretest) became moderately anxious after SEFT therapy (posttest). Although the decline was only to moderate anxiety, the patient's family said they became calmer, and a feeling of resignation appeared about the critical condition of their family members. The decrease in anxiety is also marked by a reduction in the frequency of pulse and breathing to normal after being given SEFT therapy. In conclusion, SEFT decreases the anxiety level of critical patients' families.
\end{abstract}

Keywords: Anxiety, Critical Patient, Spiritual Emotional Freedom Technique, Visual Analog Scale for Anxiety 


\section{PENDAHULUAN}

Pasien dengan fase kritis merupakan pasien dengan satu atau lebih gangguan fungsi sistem organ vital manusia yang dapat mengancam kehidupannya, sehingga membutuhkan suatu penanganan khusus dan pemantauan secara intensif. Pasien kritis mengalami perubahan dan penurunan fungsi secara fisiologis dan fisik sehingga erat kaitannya dengan tindakan intensif di rumah sakit. Pasien memerlukan monitoring dalam setiap tindakan agar perubahan fisiologis dan penurunan fisik dapat dipantau secara maksimal.

Keluarga pasien yang anggota keluarganya dalam keadaan kritis, mengalami kecemasan yang tinggi. Jika keluarga cemas maka keluarga sebagai sumber daya untuk perawatan pasien tidak berfungsi dengan baik. Selain itu kecemasan keluarga dapat dikomunikasikan kepada pasien sehingga berakibat memperparah penyakit dan menghambat proses penyembuhan (Stuart \& Laraia, 2019). Faktor resiko yang berhubungan dengan kecemasan anggota keluarga diruang perawatan intensif adalah jenis kekerabatan dengan pasien, tingkat pendidikan, tipe perawatan pasien, kondisi medis pasien, pertemuan keluarga dengan perawatan, cara penanggulangan, dan kebutuhan keluarga (Bakara et al., 2015).

Kecemasan adalah respon adaptif, dipengaruhi oleh karekteristik individual atau proses psikologis, yaitu akibat dari tindakan, situasi atau kejadian eksternal yang menyebabkan tuntutan fisik atau psikologis terhadap seseorang. Pada umumnya kecemasan merupakan fenomena normal pada pengalaman-pengalaman baru dan hal-hal yang belum pernah dicoba. Pasien yang akan dioperasi biasanya menjadi agak gelisah dan takut. Perasaan gelisah dan takut kadang tidak tampak jelas. Tetapi kadang-kadang pula kecemasan itu dapat dilihat dalam bentuk lain. Pasien yang takut sering bertanya terusmenerus dan berulang walaupun pertanyaannya telah dijawab. Pasien tidak mau bicara dan memperlihatkan sekitarnya, tetapi malah sebaliknya pasien mengalihkan perhatiannya atau sebaliknya pasien bergerak terus menerus dan tidak bisa tidur (Prabowo, 2019).

Kecemasan atau ansietas dalam diri pasien dan keluarganya selama pasien di rumah sakit, salah satunya karena khawatir dengan keadaan pasien yang akan semakin memburuk bahkan mengancam jiwa pasien. Begitu pula kondisi ruangan dimana keluarga pasien tidak boleh mendampingi pasien setiap saat dan tidak bisa melihat perkembangan pasien secara langsung akan menyebabkan keluarga pasien cemas. Dampak langsung dari kecemasan dialami oleh keluarga pasien (Stuart \& Laraia, 2019).

Kecemasan pada keluarga pasien yang kritis akan menimbulkan masalah baru yaitu ketidakmampuan keluarga dalam mengambil keputusan sehingga dapat menghambat pemberian asuhan keperawatan kepada pasien (Kozier et al., 2019). Maka dari itu, agar kecemasan tersebut tidak semakin membesar dan mengganggu aktivitas sehari-hari terutama dalam merawat anggota keluarga yang sedang sakit, untuk itu diperlukan suatu terapi yang dapat menurunkan kecemasan pada keluarga pasien yang kritis. Salah satunya adalah terapi Spiritual Emotional Freedom Technique (SEFT). SEFT dapat dilakukan sendiri dan tanpa penggunaan alat khusus sehingga terapi ini dapat dilakukan kapanpun.

SEFT merupakan salah satu terapi yang mengkombinasikan mind-body yang kemudian menjadi asuhan keperawatan komplementer. SEFT menggunakan sistem energi tubuh yang mempunyai tujuan untuk memperbaiki kondisi pikiran, emosi serta perilaku seseorang. SEFT merupakan bentuk kombinasi antara sistem energi tubuh (energi Medicine) dengan terapi spiritual dan memakai metode tapping (ketukan) beberapa titik tertentu pada titik-titik kunci dalam 12 jalur energi (energi medicine) tubuh. Teknik SEFT menambahkan unsur spiritual dalam metodenya (Prasetiyo, 2020). 
Hasil penelitian yang dilakukan Kurnianingsih et al., (2021); Revai et al., (2018) menunjukkan bahwa terapi SEFT dapat menurunkan tingkat kecemasan dan meningkatkan kualitas tidur pasien PPOK jika dilakukan secara teratur dan berkelanjutan . Intervensi tersebut berfokus untuk mengurangi masalah psikologis yang disebabkan oleh emosional atau psikosomatik.

Terapi SEFT menggunakan teknik yang aman, mudah, cepat dan sederhana bahkan tanpa risiko karena tidak menggunakan alat atau jarum. Hanya dengan jari telunjuk dan jari tengah kita yang diketuk-ketukkan ringan di beberapa titik meridian tubuh. Selain itu, dengan melibatkan Tuhan dalam proses energi psikologi sehingga spektrum masalah yang dapat diatasi juga jauh lebih luas meliputi fisik dan emosi, kesuksesan diri, kebahagiaan hati dan menjadikan jalan menuju kemuliaan diri (Rachmawati \& Aristina, 2019).

RSUD Kota Kendari merupakan salah satu rumah sakit yang menjadi pusat rujukan di Kota Kendari. Berdasarkan data rekam medik jumlah pasien yang dirawat di ruang ICCU pada tahun 2016 sebanyak 274 orang, tahun 2017 sebanyak 291 orang dan pada tahun 2018 mengalami peningkatan sebanyak 302 orang (Kendari, 2018). Berdasarkan hal tersebut, maka tingkat kecemasan keluarga pasien kritispun meningkat tiap tahunnya sehingga dibutuhkan terapi yang dapat menurunkannya yaitu SEFT yang belum dilakukan pada responden yang sama.Fokus pada penelitian ini adalah kecemasan pada keluarga pasien yang kritis.

\section{METODE PENELITIAN}

Penelitian ini merupakan penelitian kuantitatif dengan desain quasi eksperimen menggunakan pendekatan one group pretest - posttest design. Desain ini dilakukan pemeriksaan terhadap penyakit atau keadaan yang diteliti pada sekelompok subyek penelitian, kemudian dilakukan intervensi (SEFT). Setelah periode waktu yang dianggap cukup dilakukan pemeriksaan kembali terhadap penyakit atau keadaan tersebut. Penelitian dirancang dengan tahapan awal, tahapan pelaksanaan intervensi terapi SEFT, dan tahapan akhir.

Tahapan awal penelitian dilakukan dengan screening keluarga pasien yang kritis kemudian dijadikan populasi dan selanjutnya dipilih sejumlah 30 anggota keluarga sebagai sampel penelitian. Pemilihan sampel penelitian dilakukan dengan metode purposive sampling bagi sampel yang memenuhi kriteria inklusi sebagai berikut; Kriteria inklusi yaitu keluarga dekat pasien melalui hubungan darah, adopsi dan perkawinan (suami, istri, ayah, ibu, anak, saudara) yang memiliki skala kecemasan minimal $45 \mathrm{~mm}$ (cemas sedang).Berusia 18 - 60 tahun, bisa membaca dan menulis; Kriteria eksklusi yaitu keluarga pasien yang kritis sedang mengkonsumsi obat anti ansietas, mengalami gangguan dalam berkomunikasi misalnya gangguan pendengaran, dan gangguan bicara.

Tahapan berikutnya adalah tahap pelaksaan SEFT, sebelumnya keluarga pasien yang bersedia ikut dalam penelitian ini diminta untuk menandatangani informed consent dan melakukan kontrak waktu penelitian. Responden dibantu dalam pengisian kuesioner terkait data demografi dan tingkat kecemasan (pretest) dengan menggunakan kuesioner Visual Analog Scale for Anxiety (VAS-A). Pada tahap ini peneliti menjelaskan terkait cara pengisian kuesioner. Peneliti mengajarkan dan membimbing responden dalam melakukan terapi SEFT selama \pm 35 menit di sebuah ruangan yang telah ditentukan bersama-sama dengan kepala ruang ICCU dengan alokasi waktu yaitu \pm 15 menit untuk penjelasan ringkas terkait SEFT dan mengajarkan langkah-langkah untuk melakukan terapi SEFT, dan \pm 15 menit untuk melakukan SEFT versi lengkap secara mandiri dengan bimbingan dari asisten peneliti yaitu \pm 5 menit untuk fase set-up dan \pm 10 menit untuk 
fase tune-in dan tapping yang dikerjakan secara bersamaan. Setelah itu, peneliti mengukur kembali tingkat kecemasan (posttest) kepada responden setelah 5 menit pemberian terapi SEFT.

\section{HASIL PENELITIAN}

Tabel. 1

Distribusi Karakteristik Demografi

Responden Penelitian ( $\mathrm{n}=30$ )

\begin{tabular}{lll}
\hline Karakteristrik Demografi & $\mathrm{f}$ & $\%$ \\
\hline Jenis Kelamin & & \\
Laki-laki & 10 & $33,3 \%$ \\
Perempuan & 20 & $66,7 \%$ \\
\hline Umur & & \\
$18-30$ tahun & 16 & $53,3 \%$ \\
$31-40$ tahun & 1 & $3,3 \%$ \\
$41-50$ tahun & 7 & $23,3 \%$ \\
$51-60$ tahun & 6 & $20 \%$ \\
\hline Pendidikan & & \\
Tidak lulus SD & 1 & $3,3 \%$ \\
SD & 7 & $23,3 \%$ \\
SMP & 5 & $16,7 \%$ \\
SMA & 11 & $36,7 \%$ \\
Diploma/sarjana/PT & 6 & $20 \%$ \\
\hline Status Hubungan dengan Pasien & & \\
Ibu Pasien & 3 & $10 \%$ \\
Ayah Pasien & 2 & $6,7 \%$ \\
Anak Pasien & 18 & $60 \%$ \\
Istri Pasien & 1 & $3,3 \%$ \\
Suami Pasien & 2 & $6,7 \%$ \\
Kakak Pasien & 2 & $6,7 \%$ \\
Adik pasien & 2 & $6,7 \%$ \\
\hline
\end{tabular}

Berdasarkan tabel 1 terkait karakteristik responden di atas, terdapat perbedaan yang mencolok yaitu jumlah responden perempuan yang lebih banyak daripada responden lakilaki. Data menunjukkan bahwa frekuensi perempuan sebanyak 20 responden $(66,7 \%)$ dan frekuensi laki- laki sebanyak 10 responden (33,3\%). Banyaknya responden perempuan dibandingkan dengan responden laki-laki disebabkan karena sebagian besar responden perempuan belum bekerja, sehingga waktu yang dimiliki lebih banyak sedangkan responden laki-laki lebih sedikit disebabkan responden sedang bekerja atau sedang mengurus administrasi biaya perawatan anggota keluarganya yang sedang kritis.

Karakteristik yang lain juga menunjukkan sebagian besar responden berumur antara 18-30 tahun sebanyak 16 responden $(53,3 \%), 11$ responden $(36,7 \%)$ berpendidikan SMA dan berstatus sebagai anak dari pasien sebanyak 18 responden (60\%). Seorang anak memiliki kewajiban berbakti dan bertanggung jawab merawat orang tua ketika orang tua sakit dan salah satu perwujudan dalam rangka memenuhi kewajiban tersebut yaitu dengan cara menunggu dan merawat orang tua yang sedang dirawat di rumah sakit. 


\section{Pengaruh Terapi SEFT terhadap Tingkat Kecemasan pada Keluarga Pasien yang Kritis}

Tabel. 2

Hasil Pengaruh Terapi SEFT terhadap Tingkat Kecemasan pada Keluarga Pasien yang Kritis $(\mathrm{n}=30)$

\begin{tabular}{lcccc}
\hline Kecemasan Responden & Mean $($ SD) & Selisih (SD) & Nilai $p$ & IK95\% \\
\hline Kecemasan Sebelum SEFT & $85,77(9,69)$ & \multirow{2}{*}{$20,50(9,66)$} & $0,001^{\mathrm{a} *}$ & \\
Kecemasan Sesudah SEFT & $65,27(12,55)$ & & $16,89-24,11$ \\
\hline
\end{tabular}

Hasil uji paired-sample $t$ test menunjukkan nilai $p=0,05$ dan nilai Interval Kepercayaan (IK) 16,89 sampai 24,11 artinya secara statistik terdapat perbedaan yang signifikan antara sebelum dan sesudah dilakukannya terapi SEFT terhadap penurunan tingkat kecemasan keluarga pasien yang kritis karena nilai $p<0,05$ sehingga ada pengaruh terapi SEFT terhadap penurunan tingkat kecemasan keluarga pasien yang kritis di RSUD Kota Kendari.

Berdasarkan tabel 2 diperoleh nilai selisih rerata kecemasan sebelum dan sesudah dilakukan SEFT sebesar 20,50 (SD = 9,66), artinya secara klinis terdapat perbedaan yang signifikan antara sebelum dan sesudah dilakukannya terapi SEFT terhadap penurunan tingkat kecemasan keluarga pasien yang kritis karena nilai selisih rerata kecemasan $>10$ sehingga secara klinis ada pengaruh terapi SEFT terhadap penurunan tingkat kecemasan keluarga pasien yang kritis di RSUD Kota Kendari.

Penurunan kecemasan tersebut juga ditandai dengan penurunan frekuensi denyut nadi dan frekuensi pernapasan setelah dikeluarga pasien melakukan terapi SEFT secara mandiri. Hal tersebut dapat dilihat pada tabel berikut :

Tabel. 3

Distribusi Karakteristik Responden berdasarkan Frekuensi Denyut Nadi dan Pernapasan Sebelum dan Sesudah Terapi SEFT $(n=30)$

\begin{tabular}{|c|c|c|c|c|}
\hline \multirow[b]{2}{*}{ Karakteristik } & \multicolumn{2}{|c|}{ Pretest } & \multicolumn{2}{|c|}{ Posttest } \\
\hline & Mean (SD) & $\begin{array}{c}\text { Median } \\
\text { (Minimum - } \\
\text { Maximum) }\end{array}$ & Mean (SD) & $\begin{array}{c}\text { Median } \\
\text { (Minimum - } \\
\text { Maximum) }\end{array}$ \\
\hline Frekuensi Denyut Nadi & $112,43(9,13)$ & - & $88,20(11,46)$ & - \\
\hline Frekuensi Pernapasan & - & $24(18-28)$ & - & $19(16-22)$ \\
\hline
\end{tabular}

Berdasarkan tabel 3 didapatkan bahwa nilai rerata frekuensi denyut nadi sebelum dilakukan terapi SEFT adalah 112,44 dan setelah dilakukan terapi SEFT terjadi penurunan nilai rerata frekuensi denyut nadi menjadi normal yaitu 88,20. Hasil yang didapatkan untuk nilai median frekuensi pernapasan sebelum dilakukan terapi SEFT adalah 24 (1828) dan turun menjadi normal yaitu 19 (16-22) setelah dilakukan terapi SEFT. Hal tersebut menunjukkan bahwa tejadi penurunan gejala dari kecemasan keluarga pasien yang kritis yang ditandai dengan penurunan nilai rerata frekuensi denyut nadi dan penurunan nilai median dari frekuensi pernapasan menjadi normal. 


\section{PEMBAHASAN}

\section{Tingkat Kecemasan Keluarga Pasien Sebelum Dilakukan Terapi SEFT}

Berdasarkan hasil penelitian menunjukkan bahwa tingkat kecemasan keluarga pasien yang kritis di RSUD Kota Kendari sebelum dilakukan terapi SEFT (pretest) termasuk dalam kategori cemas berat dengan nilai rerata kecemasan pretest sebesar 85,77. Hasil tersebut juga didukung dengan tingginya frekuensi denyut nadi dan pernapasan yang dialami oleh responden sebelum dilakukan terapi SEFT. Peningkatan frekuensi denyut nadi dan pernapasan merupakan salah satu tanda dan gejala dari kecemasan.

Menurut Stuart \& Laraia (2019) salah satu faktor resiko yang berhubungan dengan kecemasan anggota keluarga pasien yang kritis adalah jenis kekerabatan dengan pasien. Pada penelitian ini terdapat 18 responden $(60 \%)$ berstatus sebagai anak pasien, ibu pasien sebanyak 3 responden (10\%), 2 reponden $(6,7 \%)$ sebagai ayah pasien, 1 responden $(3,3 \%)$ sebagai istri pasien, 2 responden $(6,7 \%)$ sebagai suami pasien, 2 responden $(6,7 \%)$ sebagai kakak pasien dan adik pasien sebanyak 2 responden $(6,7 \%)$. Semua status hubungan keluarga tersebut merupakan jenis kekerabatan yang dekat dengan pasien. Hal inilah yang menyebabkan responden mengalami cemas berat terhadap anggota keluarga dekatnya yang sedang kritis.

\section{Tingkat Kecemasan Keluarga Pasien Setelah Dilakukan Terapi SEFT}

Berdasarkan hasil penelitian menunjukkan bahwa tingkat kecemasan keluarga pasien yang kritis di RSUD Kota Kendari pada saat setelah dilakukan terapi SEFT (posttest) termasuk dalam kategori cemas sedang dengan nilai rerata kecemasan posttest sebesar 65,27 . Hal ini didukung dengan terjadinya penurunan frekuensi denyut nadi dan frekuensi pernapasan dari sebelumnya (pretest).

Selain data diatas juga diperoleh ungkapan verbal dari keluarga pasien bahwa mereka merasa lebih tenang, lebih pasrah dan lebih menerima kondisi anggota keluarganya dibandingkan sebelumnya (pretest). Meskipun demikian, mereka mengatakan bahwa perasaan cemas yang mereka alami tidak akan hilang jika anggota keluarganya masih dirawat di rumah sakit dan masih dalam kondisi kritis.

\section{Pengaruh Terapi Seft terhadap Tingkat Kecemasan Keluarga Pasien yang Kritis}

Berdasarkan data hasil penelitian di atas menunjukkan bahwa terapi SEFT berpengaruh secara signifikan terhadap kecemasan keluarga pasien yang kritis di RSUD Kota Kendari baik secara statistik maupun klinis. Pengaruh tersebut berupa penurunan kecemasan keluarga pasien yang kritis di RSUD Kota Kendari dari cemas berat menjadi cemas sedang. Meskipun penurunannya hanya sampai cemas sedang, akan tetapi responden mengatakan menjadi lebih tenang dan muncul perasaan pasrah akan kondisi anggota keluarganya yang sedang kritis. Hal ini tidak terlepas dari motivasi keluarga pasien untuk mengikuti terapi SEFT dan teknik terapi SEFT yang mereka lakukan sesuai dengan langkah-langkahnya yang telah diajarkan.

Terapi SEFT termasuk teknik relaksasi, merupakan salah satu bentuk mind-body therapy dari terapi komplementer dan alternatif dalam keperawatan. Teknik ini menggabungkan sistem energi tubuh (energy medicine) dan terapi spiritual yang digunakan sebagai salah satu tehnik terapi untuk mengatasi masalah emosional dan fisik, yaitu dengan melakukan ketukan ringan (tapping) pada titik syaraf (meridian tubuh). 
Terapi SEFT berfokus pada kata atau kalimat yang disampaikan berulang dengan irama yang teratur serta sikap pasrah kepada Tuhan dengan di sertai keihlasan. Terapi SEFT ini akan membuat Irama nafasnya menjadi lebih teratur, jantung berdenyut lebih teratur dan stabil sehingga sirkulasi darah yang mengalir kedalam tubuh dengan lancar dan dampak klien dalam keadaan yang luar biasa rileks, dengan demikian saat seseorang dalam keadaan rileks maka mudah untuk mengawali tidur (Fitriana, 2021).

Dalam terapi SEFT memakai rangsangan berupa Tapping atau ketukan ringan pada titik acupoint dalam tubuh. Ketika tubuh dilakukan stimulus berupa ketukan ringan atau Tapping maka respons yang muncul yaitu terjadi peningkatan mobilisasi sinyal-sinyal dalam neurotransmitter yang memberikan dampak menurunya regulasi hypothalamicpituitary-adrenal Axis (HPA axis) hingga terjadi produksi hormon stres dalam hal ini adalah kortisol menjadi berkurang (Prasetiyo, 2018).

Terapi SEFT terdiri dari dua aspek yaitu spiritual dan juga biologis. Aspek spiritual terdiri dari dua Langkah yaitu set-up yang bertujuan untuk memastikan agar aliran energi dalam tubuh terarah dengan tepat. Langkah ini di lakuakan untuk menetralisir perlawanan psikologis yang berisi do'a dan kepasrahan. Kemudian Langkah kedua yaitu tune-in dengan cara merasakan rasa sakit yang dialami, lalu mengarahkan pikiran ke rasasakit yang dialami. Aspek kedua yaitu biologis yaitu terdiri dari tapping atau ketukan ringan pada 18 titik energi tubuh yang melewati 12 jalur meridian tubuh. Ketukan yang diberikan akan merangsang "electrically active cell" sebagai pusat aktif di permukaan tubuh. Tapping yang dilakukan akan menimbulkan hantaran rangsangan berupa sinyal transduksi yang terjadi dalam proses biologis akibat rangsangan pada titik utama (Pujiati \& Febita, 2019).

Ketika dilakukan Tapping pada titik acupoint maka kan terjadi penurunan aktifitas amygdala dengan kata lain terjadi penurunan aktifvitas gelombang otak. Hal tersebut kan menimbulkan respon fight or flight pada partisipann terhenti. Untuk kemudian memunculkan efek relaksasi yang akan menetralisir segala ketegangan emosi yang dialami individu. Sementara itu jika di lihat dari aspek reaksi fisiologis SEFT, megetuk ringan pada 12 titik meridian tunuh dapat menstimulus glandpituary untuk mengeluarkan hormone endorphine dimana hormone tersebut akan memberikan efek ketenangan serta menimbulkan rasa Bahagia (Kasron, 2019).

Spiritual dalam SEFT adalah doa yang diafirmasikan oleh keluarga pada saat akan dimulai hingga sesi terapi berakhir, yaitu pada fase set-up, tune-in dantapping. Pada fase set-up, keluarga pasien diminta untuk berdoa kepada Tuhan dengan penuh rasa khusyu', ikhlas dan pasrah bahwa kecemasan yang dialami saat ini terkait kondisi anggota keluarganya yang sakit, kita ikhlas menerima dan kita pasrahkan kesembuhan nya pada Tuhan Yang Maha Esa. Pada fasetune-in, dilakukan dengan cara merasakan rasa sakit yang dialami, lalu mengarahkan pikiran ke tempat rasa sakit, dibarengi dengan hati dan mulut mengucapkan doa "Ya Allah meskipun saya merasa cemas atas kondisi anggota keluarga saya yang kritis, saya ikhlas menerima rasa cemas ini dan saya pasrahkan kepada-Mu kebaikan hati dan pikiran saya". Bersamaan dengan tune in ini kita melakukan fase ketiga yaitu tapping..

Motivasi dan sikap beribadah yang ikhlas dapat dijadikan alternatif sebagai psikoterapi suportif yang dapat menstabilkan hormon stres yang biasanya terpicu dalam jumlah banyak ketika stresor yang dating bertubi - tubi dan menyebabkan gejala psikosomatis. Terapi pasien di rumah sakit gangguan psikosomatik biasanya disarankan untuk mempertinggi ibadahnya sehingga selain diberikan pengobatan somatoterapi, maupun manipulasi lingkungan juga diberikan beberapa tuntunan ibadah, seperti menjalankan shalat lima waktu, shalat tahajjud pada sepertiga akhir malam, 
puasa sunnah, dzikir dan sedekah. Nasehat secara verbal dapat memberi support kepada pasien agar dapat menjalani hidup ini dengan lebihrileks (Sumiati, 2018).

Bakara et al., (2015) menyebutkan bahwa terapi spiritual menimbulkan respon relaksasi dan kesehatan, dapat menimbulkan keyakinan dalam perawatan diri, dan bermanfaat terhadap kecemasan dan panik pada pasien terminal yang dapat menimbulkan ketenangan. Selain itu menurut Kozier et al., (2019) keyakinan spiritual akan memberikan rasa tenang dan harapan positif bagi yang mengalami sakit, sehingga diharapkan dapat menurunkan kecemasannya.

Kepercayaan spiritual memiliki efek yang kuat terhadap fungsi psikologis dalam penelitian yang dilakukan pada pasien kanker. Tingkat putus asa, keinginan bunuh diri dan kematian lebih rendah pada pasien kanker yang mendapatkan terapi spiritual. Keyakinan ini memiliki hubungan dengan tingkat depresi atau kecemasan, karena spiritual didefinisikan sebagai tujuan hidup dan keyakinan seseorang.

Beberapa uraian di atas menjelaskan bahwa manfaat dari pendekatan spiritual bagi keluarga pasien yang cemas karena anggota keluarganya yang sedang kritis adalah memberikan ketenangan, harapan dan memperkuat mental keluarga pasien. Keluarga pasien menjadi lebih rileks menjalani kesehariannya.

\section{SIMPULAN}

Secara statistik dan klinis, SEFT berpengaruh terhadap penurunan tingkat kecemasan keluarga pasien yang kritis.

\section{SARAN}

SEFT dapat digunakan oleh perawat di rumah sakit sebagai terapi non farmakologi utuk menurunkan kecemasan keluarga pasien yang kritis. Penelitian selanjutnya dapat dikembangkan ke gejala pasien lain seperti menurunkan nyeri atau variabel lain yang sesuai.

\section{DAFTAR PUSTAKA}

Bakara, D. M., Ibrahim, K., \& Sriati, A. (2015). Efek Spiritual Emotional Freedom Technique terhadap Cemas dan Depresi, Sindrom Koroner Akut. Jurnal Keperawatan Padjadjaran, 1(1). http://dx.doi.org/10.24198/jkp.v1i1.51

Fitriana, N. (2021). Terapi Seft (Spiritual Emosional Freedom Technique) pada Remaja dalam Upaya Peningkatan Kualitas Tidur pada Kasus Insomnia. Universitas Muhammadiyah Magelang

Kasron, S. (2019). Pengaruh Spiritual Emotional Freedom Tehnique (Seft) terhadap Kualitas Tidur Penderita Hipertensi. Journal of Islamic Nursing Hubungan, 3(7), 123-128. https://ejournal.uhb.ac.id/index.php/VM/article/view/324

Kendari. (2018). Laporan Tahunan Unit Rekam Medis RSUD Kota Kendari

Kozier, B., Erb, G., Berman, A., \& Snyder, S. (2019). Buku Ajar Fundamental Keperawatan: Konsep, Proses dan Praktik. Jakarta: EGC

Kurnianingsih, M. F., Nahdatien, I., \& Zahro, C. (2021). Spiritual Emotional Freedom Technique (SEFT) Berpengaruh terhadap Kecemasan dan Motivasi Sembuh Pasien COVID-19. Jurnal Keperawatan, 13(3), 665-682. http://journal.stikeskendal.ac.id/index.php/Keperawatan

Prabowo, R. K. (2019). Efektivitas Terapi Spiritual Emotional Freedom Technique (SEFT) terhadap Tingkat Kecemasan pada Pasien Pre Operasi Bedah Jantung. Indonesian 
$\begin{array}{llll}\text { Jurnal of Health } & \text { Development, } & \text { 1(2), }\end{array}$ https://ijhd.upnvj.ac.id/index.php/ijhd/article/view/17

Prasetiyo, H. (2020). Pengaruh Spiritual Emotional Freedom Technique (Seft) terhadap Kualitas Tidur Pasien Rawat Inap Kelas III di Rsud Sleman Yogyakarta. Universitas Alma Ata Yogyakarta. http://elibrary.almaata.ac.id/1707/

Pujiati, E., \& Febita, I. (2019). Pengaruh Spyritual Emotional Freedom Technique (SEFT) terhadap Penurunan Tingkat Insomnia pada Penderita HIV / IDS. Jurnal Profesi http://jurnal.akperkridahusada.ac.id/index.php/jpk/article/view/59

Rachmawati, N \& Aristina, T. (2019). Pengaruh Terapi Spiritual Emosional Freedom Technique (SEFT) terhadap Stress Mahasiswa di Akademi Keperawatan YKY $\begin{array}{llll}\text { Yogyakarta. Jurnal } & \text { Ners }\end{array}$ http://journal.wima.ac.id/index.php/NERS/article/view/2496

Revai, A. (2018). Pengaruh Spiritual Emotional Freedom Tehnique (SEFT) terhadap Kecemasan, Saturasi Oksigen dan Kualitas Tidur pada Pasien Penyakit Paru Obstruktif Kronik (PPOK). Universitas Airlangga. https://repository.unair.ac.id/78281/

Stuart, G. W., \& Laraia, M. (2019). Prinsip dan Praktik Keperawatan Psikiatrik. Jakarta: EGC 